\title{
The Dynamic of Blue-Green Algae (Cyanobacteria) in Eutrophic Tropical Waters, The Cirata Reservoir
}

\author{
Fariha Luthfiani a , Hikmat Kasmara a, Sunardi a,b,* \\ ${ }^{a}$ Department of Biology, Faculty of Mathematics and Natural Sciences, Universitas Padjadjaran, Indonesia; Jl. \\ Raya Bandung-Sumedang Km. 21, Jatinangor, Sumedang 45363, West Java, Indonesia; \\ fariha15001@mail.unpad.ac.id \\ ${ }^{\mathrm{b}}$ Graduate Program of Environmental Studies, Post-Graduate School, Universitas Padjadjaran; J1. Sekeloa \\ Selatan 1, Bandung 40132, West Java, Indonesia; sunardi@unpad.ac.id
}

\begin{abstract}
The quality of reservoir waters depends on changes in their physical, chemical, and biological components. Changes in these parameters lead to the emerging of many problems in the reservoir, such as eutrophication and changes in the composition of the phytoplankton community in the reservoir ecosystem. This eutrophication impact can trigger an explosion of dangerous phytoplankton population, such as blue-green algae (Cyanobacteria). Research on the relationship between water quality and the community structure of Cyanobacteria has been carried out. This study used secondary data from the water monitoring report of the Cirata Reservoir from 2013-2017. This study aimed to obtain information on the community structure of Cyanobacteria and environmental parameters that affected the abundance of Cyanobacteria in the reservoir. Species abundance, diversity index, and dominance index were analyzed to determine changes in the community structure of Cyanobacteria in each of the years. Cyanobacteria abundances were classified using cluster analysis. Water quality parameters such as temperature, transparency, $\mathrm{pH}$, carbon dioxide, nitrate, nitrite, and zooplankton abundance as independent variables, and levels of Cyanobacteria abundances as the dependent variable was analyzed using discriminant analysis. This study showed that the abundance of Cyanobacteria in the Cirata Reservoir is dominated by the Stanieria (a genus of the Pleurocapsales order) every year and the parameter that significantly affects the level of Cyanobacteria abundance was nitrate $\left(\mathrm{NO}_{3}-\mathrm{N}\right)$.
\end{abstract}

Keywords: Water Quality, Cyanobacteria, Abundance, Cirata Reservoir

\section{INTRODUCTION}

Water is the unavoidable requirement for living things, and reservoirs are aquatic ecosystems that play important role in water provision (Kartini \& Permana, 2016). To date, human activities and climate change have posed a severe threat to water quality. The quality of reservoir waters depends on changes in the physical, chemical, and biological parameters of the system. Increasing temperature, changes in

* Corresponding Author

E-mail: sunardi@unpad.ac.id

CMLI 2020 rainfall, and high nutrient input from human activities can change the physical, chemical, and biological components of the reservoirs. Changes in these components lead to problems in the reservoirs, one of which is eutrophication and changes in the phytoplankton structure in the reservoirs. This eutrophication impact can further trigger a population explosion of harmful phytoplankton, such as green-blue algae (Cyanobacteria) (Satya et al., 2018; Sulastri et al., 2019).

The dominance and high abundance of Cyanobacteria can cause organoleptic changes 
(color, taste, smell, and turbidity) of waters and corrosion of water storage facilities in reservoirs. Besides, waters can become toxic due to secondary metabolites produced by Cyanobacteria, eg. Microcystin, as a form of selfdefense (PT. LAPI ITB, 2017). The function of the reservoir to serve energy provision, fish cultivation for floating net cages (KJA), water supply, and tourism can be disrupted.

Environmental parameters play an important role in supporting the reproduction of Cyanobacteria. In general, the existence of Cyanobacteria itself is influenced by physical parameters (temperature, light, brightness, and dissolved gases), chemical parameters ( $\mathrm{pH}$ and nutrients), and zooplankton as predators (Wijaya, 2009). Knowing the parameters that trigger the abundance of cyanobacteria in waters is very important. Controlling the parameters that trigger the growth of Cyanobacteria can be a precautionary measure for the occurrence of the population explosion of Cyanobacteria.

Cirata Reservoir is categorized as eutrophic tropical water which was built in the Citarum Watershed (DAS). The water flow originating from the river inlets, and the increasing number of floating net cages will determine the water quality. As a result, Cirata Reservoir was contaminated with organic and inorganic materials (Novia, 2016). The water monitoring report from 1996-2013 showed that Cyanobacteria was a class of phytoplankton that dominated the Cirata Reservoir, with a percentage of $41.13 \%$ after Bacillariophyta (Sunardi et al., 2017). This phenomenon indicated that some environmental parameters had triggered the growth of Cyanobacteria in the reservoir. This study investigates the structure of the Cyanobacteria community, and determines which environmental parameters that affect the high or low abundance of the Cyanobacteria in such eutrophic waters.

\section{METHODS}

\section{Water Quality and Cyanobacteria Abundance}

Cirata Reservoir water quality monitoring for the period 2013-2017 has been carried out by the Badan Pengelolaan Waduk Cirata Pembangkitan Jawa Bali, BPWC-PJB. The water quality of the Cirata Reservoir is reported quarterly consisting of physical, chemical, and biological parameter data. The data were selected and verified according to research needs. This study used water quality parameter data (physical, chemical, and biological) covering from the depth of $0.2 \mathrm{~m}$ at 9 stations in the Cirata Reservoir (Figure 1). The physical, chemical and biological parameters used were water temperature, water transparency, carbon dioxide $\left(\mathrm{CO}_{2}\right)$ levels, $\mathrm{pH}$, nitrate $\left(\mathrm{NO}_{3}-\mathrm{N}\right)$, phosphate $\left(\mathrm{PO}_{4}-\mathrm{P}\right)$, and zooplankton abundance. These parameters affect the growth of Cyanobacteria. Data on the type and abundance of Cyanobacteria were taken from the tabulation data from the monitoring report.

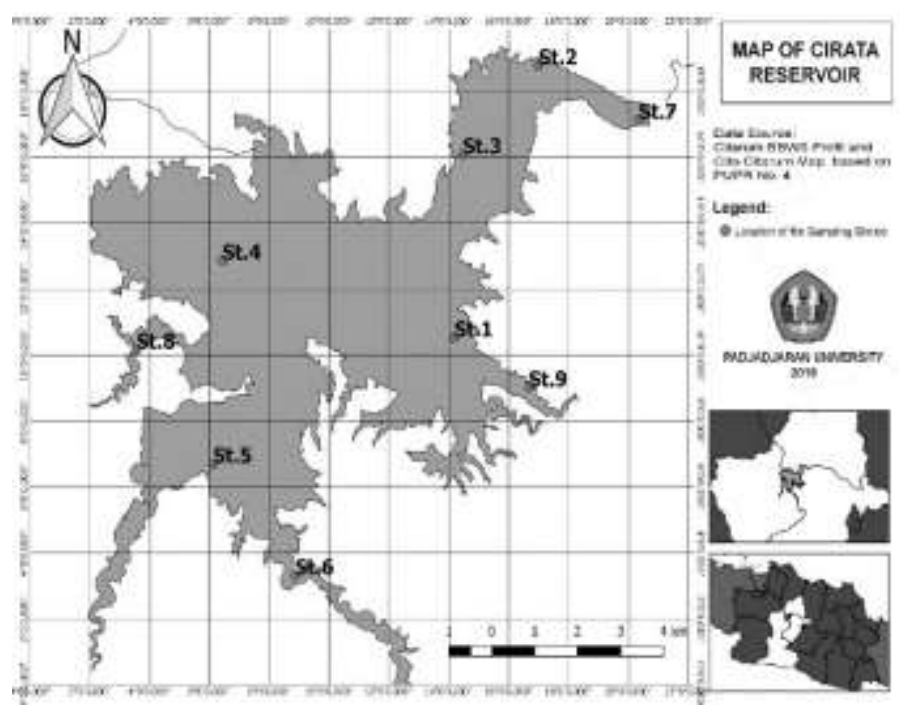

Figure 1. The Cirata Reservoir and Sampling Stations selected in the study

\section{Cyanobacteria Community Structure}

The community structure of the Cyanobacteria can be viewed from the three calculated parameters, namely species abundance, diversity index, and dominance index. Abundance was directly adopted from the monitoring report. Meanwhile, the diversity index was calculated using the Shannon-Wiener 
diversity formula (1) (Wilhm \& Dorris, 1968). While the dominance index was calculated using the Simpson dominance formula (2) (Odum, 1996).

$$
H^{\prime}=-\sum_{i=1}^{n} p i \operatorname{lnpi}
$$

Where $\mathrm{H}$ 'is the Shannon-Wiener diversity index, $p i$ is $n i / \mathrm{N}$ ( $n i$ is number of individuals of the family, $\mathrm{N}$ is the total number of individuals). The diversity index is categorized as 'low' if $\mathrm{H}$ ' 1 , 'medium' if $1<\mathrm{H}^{\prime} \leq 3$, and 'high' if $\mathrm{H}^{\prime} \geq 3$.

$$
\mathrm{D}=\sum_{i=1}^{n}(n i / N)^{2}
$$

Where D is Simpson's dominance index, $n i$ is the number of the individuals, $\mathrm{N}$ is the total number of individuals. If the $\mathrm{D}$ value approaches 0 then there were no species dominated, and if the $\mathrm{D}$ value approaches 1 then there were species that dominated the community.

\section{Data Analysis}

This research employed two statistical analyzes, namely cluster analysis, and discriminant analysis. Cluster analysis was meant to group the members of Cyanobacteria in such a way that members in the same group (called a cluster) are more similar (in some sense) to each other than to those in other groups (clusters). While discriminant analysis was used to classify observations into non-overlapping groups, based on scores on one or more quantitative predictor variables. Data of abundance at each station in each period were analyzed using cluster analysis to group their abundance level/category, i.e., low, medium, high to find the factors determining the dynamics of the abundance levels before the discriminant analysis was performed.

\section{RESULTS AND DISCUSSION}

\section{Results}

\section{Water Quality Parameters}

The results indicated that the water quality parameters of Cirata Reservoir during the period 2013-2017 were dynamic. No specific pattern was found regarding the temporal or seasonal dynamics of the water quality. The highest average temperature was occurred at $4^{\text {th }}$ quarter of 2014 with a temperature of $30.83^{\circ} \mathrm{C}$, while the lowest was in 2017 in the $3^{\text {rd }}$ quarter with a temperature of $28.29^{\circ} \mathrm{C}$. The highest average transparency was in the $4^{\text {th }}$ quarter of 2017 with a depth of $120 \mathrm{~cm}$, and the lowest was in the 4th quarter of 2013 with a depth of $66.33 \mathrm{~cm}$. The highest average $\mathrm{pH}$ value was found in the $2 \mathrm{nd}$ quarter of 2016 with a value of 6.51, and the lowest was in 2015, the $3^{\text {rd }}$ quarter with a value of 8.35. The highest average nitrate $\left(\mathrm{NO}_{3}-\mathrm{N}\right)$ levels were found in the $3^{\text {rd }}$ quarter of 2014 with levels of $0.89 \mathrm{mg} / \mathrm{L}$, and the lowest was in 2016, the $4^{\text {th }}$ quarter with a level of $0.01 \mathrm{mg} / \mathrm{L}$. Meanwhile, the highest average phosphate level $\left(\mathrm{PO}_{4}-\mathrm{P}\right)$ was found in the $4^{\text {th }}$ quarter of 2014 with a level of $0.32 \mathrm{mg} / \mathrm{L}$, and the lowest was in 2015 , the $4^{\text {th }}$ quarter with a level of $0.02 \mathrm{mg} / \mathrm{L}$. For zooplankton, the highest average was in the $2^{\text {nd }}$ quarter of 2013 with a total of $37,581 \mathrm{ind} / \mathrm{L}$, while the lowest was in 2017 in the $4^{\text {th }}$ quarter with a total of $495 \mathrm{ind} / \mathrm{L}$.

\section{Cyanobacteria Community Structure}

During 2013-2017, 7 orders and 23 genera of Cyanobacteria were found, the group consisted of Chroococcales (5 genera), Nostocales (5 genera), Oscillatoriales (4 genera), Pleurocapsales (1 family), Spirulinales (1 genus), Stigonematales (3 genera), and Synechococcales (4 genera). The Cyanobacteria community was dominated by the order Pleurocapsales followed by Oscillatoriales, then Chroococcales, and Synechococcales respectively. The abundance of Cyanobacteria ranged from 4,521 ind/L - 128,337 ind/L. While Stanieria was the genus with the highest abundance at any period.

The diversity index value $\left(\mathrm{H}^{\prime}\right)$ of Cyanobacteria in Cirata Reservoir ranged from 0.085-1.612. The water diversity index criteria of Cirata Reservoir in 2013 (quarter 2, 4), 2014 (quarter 3, 4), 2015 (quarter 1, 2, 3, 4), and 2016 (quarter 1,2) were regarded as low with an index of $\leq 1$, while in 2016 (quarter 4) and 2017 (quarter 3,4) with index >1 was regarded as moderate. 
The dominance index value of Cirata Reservoir waters during 2013-2017 ranged from 0.298 to 0.973 . In a point with a diversity index of $\leq 1$, the dominance index was close to 1 . These happened in 2013, 2014, and 2016 in quarters 1 and 2. This indicated that some species dominate the community, as it was obvious that Stanieria sp. dominated the Cyanobacteria community. At the end of the period, i.e., 2016 the 4th quarter, and 2017 the 3rd and 4th quarter, it showed the diversity index increased to $>1$, and the dominance index decreased.

Water Quality - Cyanobacteria Abundance Relation

The cluster analysis of the abundance of Cyanobacteria resulted in three groups of Cyanobacteria abundance, i.e., low, medium, and high (Table 1).

Table 1. Cyanobacteria Abundance Groups based on Cluster Analysis in Individual/Liter

\begin{tabular}{cccc}
\hline & $\mathbf{1}$ & $\mathbf{2}$ & $\mathbf{3}$ \\
& $($ Low $)$ & $($ Medium $)$ & (High) \\
\hline Total & 98 & 8 & 2 \\
Min & 66 & 19.272 & 35.772 \\
Max & 14.883 & 31.779 & 41.731 \\
Range & $<15.000$ & $15.000-32.000$ & $>32.000$ \\
\hline
\end{tabular}

*in ind/L units

The decision from the discriminant analysis concerning the abundance of Cyanobacteria and water quality can be taken in two ways; from the Wilks' Lambda number and the F test. In Table 2, it can be seen that the Wilks' Lambda number ranges from 0.903-1.000, with the nitrate parameter as the farthest variable from 1 . While the results of the discriminant analysis of the abundance of Cyanobacteria with water quality through the $\mathrm{F}$ test can be seen by looking at the significance values on the table. The variable on the table that has a significant value $<0.05$ was nitrate. This shows that the environmental parameter that significantly affected the dynamics of Cyanobacteria abundance was the nitrate level.
Table 2. Discriminant Analysis between Parameters and Cyanobacteria Abundance Group in Cirata Reservoir

\begin{tabular}{ccccccc}
\hline Parameter & Low & Medium & High & $\begin{array}{c}\text { Wilks' } \\
\text { Lambda }\end{array}$ & F & Sig. \\
\hline Temperature & 30,028 & 30,2 & 31 & 0,987 & 0,697 & 0,5 \\
Transparency & 99,194 & 83,125 & 87,5 & 0,983 & 0,925 & 0,4 \\
$\mathbf{p H}$ & 7,356 & 7,345 & 7,31 & 1,000 & 0,005 & 0,995 \\
$\mathbf{C O}_{\mathbf{2}}(\mathbf{m g} / \mathbf{L})$ & 5,196 & 6,665 & 4,95 & 0,996 & 0,210 & 0,811 \\
Nitrate (mg/L) & 0,388 & 0,726 & 0,562 & $0,903^{*}$ & 5,662 & 0,005 \\
$\begin{array}{c}\text { Phosphate } \\
(\mathbf{m g} / \mathbf{L})\end{array}$ & 0,160 & 0,185 & 0,246 & 0,989 & 0,592 & 0,555 \\
$\begin{array}{c}\text { Zooplankton } \\
(\text { Ind/L) }\end{array}$ & 15349 & 32265 & 8003 & 0,947 & 2,936 & 0,057 \\
\hline
\end{tabular}

*Parameters that have a significant effect

\section{Discussion}

In general, the water quality parameters of Cirata Reservoir such as temperature, transparency, $\mathrm{pH}, \mathrm{CO}_{2}$, nitrate, phosphate levels, and the abundance of zooplankton were in the range to support the growth of Cyanobacteria, marked by the presence of Cyanobacteria in each period. Referring to the diversity index and dominance index, it can be regarded that the reservoir has low to moderate diversity with a dominance of the genus of Cyanobacteria. When viewed from the stability, based on the ShannonWiener diversity index, Cirata Reservoir water is categorized as low community diversity and stability (Basmi, 1999). In such circumstances, this can easily affect the structure and composition of the genera, even by relatively small environmental changes (Tarunamulia et al., 2016).

The Cyanobacteria in Cirata Reservoir consisted of 7 orders and 23 genera of Cyanobacteria, several genera such as Stanieria, Oscillatoria, Phormidium, and Microcystis always present during years of 2013-2017. In this study, the highest cyanobacteria abundance occurred in the 4th quarter of 2014 during the dry season with a total of $128,337 \mathrm{ind} / \mathrm{L}$. According to Mur et al. (1999), this can be influenced by genetic conditions, and the ability of Cyanobacteria to adapt to a wide range of environmental conditions as discussed below. The Cyanobacteria in the Cirata Reservoir also consisted of toxic-producing species, such as 
Anabaena, Lyngbya, and including Oscillatoria, Phormidium, and Microcystis.

Stanieria placed the highest abundance in this period, which also happened in 1995-2013 as indicated by Sunardi et al. (2017). In that period, Stanieria showed its dominance in the mid to late period of the study when temperatures were slightly higher than average. The warmer environment might stimulate the faster regeneration. One thing that can affect the high abundance of Stanieria is the ability to reproduce faster than the other genera. According to Mur et al. (1999), in contrast to other orders of Cyanobacteria, Pleurocapsales can reproduce in two ways, namely binary fission and double fission so that their reproduction is more rapid than the other genera.

Several genera such as Oscillatoria and Microcystis have capacity to deal with fluctuating environmental conditions. Microcystis is a cosmopolitan genus of Cyanobacteria and has a wide tolerance for environmental conditions (Masithah, 2011). Moreover, Microcystis can form a kind of gas bubble to float on the water surface to get an optimal location for its growth (Mur et al., 1999). This can be an advantage in competition with other species. Microcystis can also produce microcystin which supports the defense against the competition with other phytoplankton or predation by zooplankton and fish. It is confirmed by Hulot \& Huisman (2004) that there are poisonous cyanobacteria that can paralyze the green algae Chlamydomonas, for example, Microcystis. Similarly, Oscillatoria can also adapt to any amount of pollution load in the water, while its filamentous structure, hard and toxic cell walls make it avoided by predation (Fahrur et al., 2012). Meanwhile, Phormidium can present at any conditions because it is cosmopolitan, and has the same structure as Oscillatoria.

The discriminant analysis result showed that the difference in high and low abundance of Cyanobacteria in the Cirata Reservoir is determined by Nitrate $\left(\mathrm{NO}_{3}-\mathrm{N}\right)$ levels in the water. As indicated by Mur et al. (1999), for phytoplankton, the need for nitrate is greater than those for phosphate. The ratio of nitrate and phosphate levels required by Cyanobacteria is 10-16:1. Nitrate level affects its growth rate; the higher the nitrate level, the more accelerated the growth of Cyanobacteria (Kim et al., 2017). Nitrate is the primary nutrient needed for the growth of phytoplankton including Cyanobacteria. Thus, the nitrate level is a significant factor affecting the growth rate of Cyanobacteria and plays as the most important controller for the abundance of Cyanobacteria in the eutrophic water.

\section{CONCLUSION}

Cyanobacteria community structure in Cirata Reservoir consists of 7 orders and 23 genera, the highest abundance is $128,337 \mathrm{ind} / \mathrm{L}$ in the 4 th quarter of 2014. Based on the Shannon-Wiener diversity index and Simpson dominance index, it can be seen that the Cyanobacteria community structure in Cirata Reservoir has low to moderate diversity. It also found that the dominant (high dominance) genus was Cyanobacterium (Stanieria) from the order of Pleurocapsales.

Several poisonous cyanobacteria such as Anabaena, Lyngbya, Oscillatoria, Phormidium, and Microcystis were also found in Cirata Reservoir. The environmental parameter that significantly affects the high and low abundance of Cyanobacteria based on the discriminant analysis that has been carried out was the nitrate $\left(\mathrm{NO}_{3}-\mathrm{N}\right)$ parameter.

\section{ACKNOWLEDGEMENTS}

The authors would like to thank CESS Unpad, Bandung Institute of Technology, and the Public Works Agency in Indonesia for data sharing of Cirata water quality. We would also like to extend our gratitude to PT. PJB BPWC for their support of our study. The authors may also thank the Department of Biology, Faculty of Mathematics and Natural Sciences, Padjadjaran University. 


\section{REFERENCES}

Basmi J. 1999. Planktonologi: Plankton sebagai Bioindikator Kualitas Perairan. Fakultas Perikanan dan Ilmu Kelautan IPB, Bogor, Indonesia.

Fahrur M, Makmur, and Rachmansyah. 2012. Dinamika kualitas air dan hubungan kelimpahan plankton dengan kualitas air di tambak kecamatan Bontoa, kabupaten Maros. Prosiding Indoaqua-Forum Inovasi Teknologi Akuakultur, 881-894.

Hulot FD \& Huisman J. 2004. Allelopathic interaction between phytoplankton species: the roles of heterotrophic bacteria and mixing intensity. Limnology and Oceanography, 49, 1424-1434.

Kartini T \& Permana S. 2016. Analisis operasional Waduk IR. H. Djuanda. Jurnal Kalibrasi Sekolah Tinggi Teknologi Garut, 14(1).

Kim, Hocheol., Bok Yeon Jo, and Han Soon Kim. 2019. Effect of different concentrations and ratios of ammonium, nitrate, and phosphate on the growth of the blue-green alga (cyanobacterium) Microcystis aeruginosa isolated from the Nakdong River, Korea. Algae, 32(4), 275-284.

Masithah ED. 2011. Upaya menurunkan dominansi Microcystis aeruginosa menggunakan enzim pektinase dar Pseudomonas pesudomalle. Berkala Penelitian Hayati Edisi Khusus C, 4, 8386.

Mur LR, Olav MS, and Hans U. 1999. Cyanobacteria in the environment. Toxic Cyanobacteria in Water: A Guide to their public health consequences, WHO. Chapter 2. https://www.who.int/water_sanitation_health/pub lications/toxicyanobact/en/
Novia F. 2016. Potensi beban pencemaran nitrogen dari inlet sungai ke Waduk Cirata, Jawa Barat. Seminar Nasional Sains dan Teknologi Lingkungan II.

Odum EP. 1996. Dasar-dasar Ekologi. Edisi 3, Gadjah Mada University Press, Yogyakarta, Indonesia.

PT. LAPI ITB. 2017. Pemantauan Kualitas Air Waduk Cirata Tri Wulan IV Tahun 2017, ITB, Bandung, Indonesia.

Satya A, Sulawesty F, Harimawan A, and Setiadi T. 2018. Correlation of Aquatic Parameters to the Cadmium Bioaccumulation Capability onto Microalgae Biomass in an Urban Lake. Journal of Water Sustainability, 8(2), 59-72.

Sulastri., Henny C, and Nomosatryo S. 2019. Keanekaragaman fitoplankton dan status trofik Perairan Maninjau di Sumatera Barat, Indonesia. Prosiding Seminar Nasional Masyarakat Biodiversitas Indonesia, 5(1), 242-250.

Sunardi, Rina F, Budi I, and Mutia SS. 2017. The dynamic of phytoplankton community structure in face of a warming climate in a tropical manmade lake. Biosintifika, 9(1), 140-147.

Tarunamulia, Kamariah, and Akhmad M. 2016. Keterkaitan spasial kualitas lingkungan dan keberadaan fitoplankton berpotensi HABs pada tambak ekstensif di kecamatan Losar kabupaten Cirebon, Jawa Barat. Jurnal Riset Akuakultur, 11(2), 181-195.

Wijaya HK. 2009. Komunitas Perifiton dan Fitoplankton serta Parameter Fisika-Kimia Perairan sebagai Penentu Kualitas Air di Bagian Hulu Sungai Cisadane, Jawa Barat, IPB, Bogor, Indonesia. 